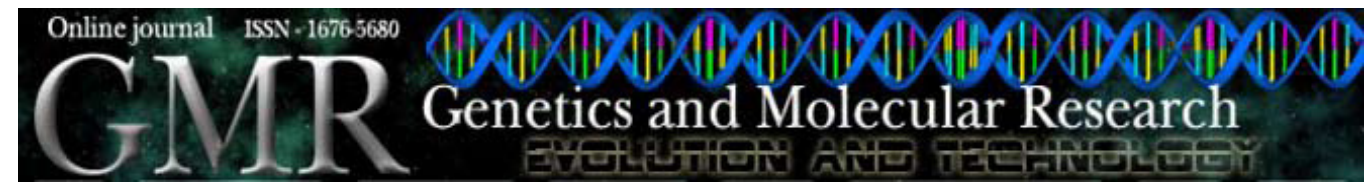

\title{
Production of the refolded oligopeptide-binding protein (OppA) encoded by the citrus pathogen Xanthomonas axonopodis pv. citri
}

\author{
A. Balan, C.S. Souza, R.C.C. Ferreira and L.C.S. Ferreira \\ Departamento de Microbiologia, Instituto de Ciências Biomédicas II, \\ Universidade de São Paulo, São Paulo, SP, Brasil \\ Corresponding author: A. Balan \\ E-mail: abalan@usp.br
}

Genet. Mol. Res. 7 (1): 117-126 (2008)

Received November 19, 2007

Accepted January 2, 2008

Published February 1, 2008

\begin{abstract}
The oligopeptide-binding protein, OppA, binds and ushers oligopeptide substrates to the membrane-associated oligopeptide permease (Opp), a multi-component ABC-type transporter involved in the uptake of oligopeptides expressed by several bacterial species. In the present study, we report the cloning, purification, refolding and conformational analysis of a recombinant OppA protein derived from Xanthomonas axonopodis pv. citri (X. citri), the etiological agent of citrus canker. The oppA gene was expressed in Escherichia coli BL21 (DE3) strain under optimized inducing conditions and the recombinant protein remained largely insoluble. Solubilization was achieved following refolding of the denatured protein. Circular dichroism analysis indicated that the recombinant OppA protein preserved conformational features of orthologs expressed by other bacterial species. The refolded recombinant OppA represents a useful tool for structural and functional analyses of the $X$. citri protein.
\end{abstract}

Key words: OppA; Xanthomonas citri; Refolding 


\section{INTRODUCTION}

Bacterial oligopeptide-binding proteins (OppA) mediate the binding of oligopeptides required for nutrition in several bacterial species and participate in diverse physiological functions including recycling of cell wall muropeptides in Escherichia coli and Salmonella typhimurium (Goodell and Higgins, 1987), sporulation control in Bacillus subtilis (Perego et al., 1991; Perego, 1997), modulation of gene expression among different Gram-positive bacterial species (Rudner et al., 1991; Lazazzera et al., 1997), and regulation of virulence-associated factors (Perego et al., 1991; Perego, 1997; Borezee et al., 2000; Claverys et al., 2000; Gominet et al., 2001).

Xanthomonas axonopodis pv. citri (X. citri) causes citrus canker, a disease affecting most orange cultivars around the world, inflicting significant economic loss to farmers and industry (Lee et al., 2004). So far, the control of the citrus canker has relied mainly on the identification and eradication of infected trees (Brunnings and Gabriel, 2003). The recent report of the complete genomic sequences of two Xanthomonas species, including the X. citri 306 strain, created perspectives concerning the development of more efficient and rational control methods based on a better knowledge of the pathogen's genetics and physiology (Da Silva et al., 2002).

$X$. citri OppA belongs to the opp operon and is composed of two transmembrane poreforming domains (OppBC) and two nucleotide-binding domains (OppDF) responsible for the generation of energy required for the transport process. The presence of the opp operon in $X$. citri but not in $X$. campestris, phytopathogens with distinct host specificities and infection mechanisms, suggests that oligopeptides may have different physiological roles for the two species. The presence of OppA, a 59.9-kDa periplasmic protein, has been demonstrated by Western and Northern blot analysis of X. citri cellular fractions (Moutran et al., 2004). Nonetheless, further structural and functional analyses require the availability of purified protein in a soluble and stable form. In order to generate material for such studies, we report the successful expression and purification of a recombinant protein that remained soluble following denaturation and refolding steps preserving conformational features of known bacterial orthologs.

\section{MATERIAL AND METHODS}

\section{Strains and plasmids}

The opp $A$ gene was obtained from $X$. citri 306 strain, cloned into the pGEM T-Easy vector (Promega) and sub-cloned into the $\mathrm{pET} 28 \mathrm{a}$ expression vector (Novagen). The recombinant protein was expressed in E. coli BL21 (DE3) (Stratagene).

\section{Cloning of the oppAX. citri gene}

The nucleotide sequence encoding the mature X. citri OppA (without the 19 encoding the amino acid long signal peptide) was amplified by PCR (forward primer, 5' CAGTCAGCTAGCACCGCT 3' and reverse primer, 5' CGCAAAAGCTTTCATTTGC 3') using Platinum high-fidelity Taq polymerase (Invitrogen) and standard amplification conditions: an initial step of $5 \mathrm{~min}$ at $96^{\circ} \mathrm{C} \mathrm{(1),2} \mathrm{min}$ at $96^{\circ} \mathrm{C} \mathrm{(2),} 1 \mathrm{~min}$ at $66^{\circ} \mathrm{C} \mathrm{(3),2} \mathrm{min}$ at $73^{\circ} \mathrm{C} \mathrm{(4),}$ followed by the repetition of the steps 2 to 4 by 29 times. The final extension was performed at $73^{\circ} \mathrm{C}$ for $10 \mathrm{~min}(5)$. The forward primer included an NheI restriction site while the reverse primer 
carried an HindIII site (underlined). The resulting amplified fragment, with a total length of 1557 $\mathrm{bp}$, was first cloned into the vector pGEM T-Easy (Promega) using standard cloning conditions. After transformation of E. coli DH5 $\alpha$ cells and screening of recombinant colonies, a recombinant plasmid named pGEMOppA was selected, amplified and cleaved with NheI and HindIII enzymes (Invitrogen) in order to release a 1.6-kbp fragment, which was purified from agarose gels and subsequently cloned into the expression vector pET28a (Novagen), previously treated with NheI/ HindIII. Transformation efficiencies of approximately $10^{8} \mathrm{CFU} / \mu \mathrm{g}$ DNA were routinely achieved with chemically competent $E$. coli $\mathrm{DH} 5 \alpha$ cells. One recombinant colony, selected out of twenty chosen colonies, was subjected to restriction analysis and nucleotide sequencing. The recombinant plasmid, named pETOppA, was further purified and introduced into the E. coli BL21 (DE3) strain (Novagen). One clone chosen at random among a lawn of recombinant colonies was selected for further analysis for expression and purification of the recombinant protein. The X. citri OppA was expressed as a cytoplasmic protein with a $\mathrm{His}_{6}$-tag genetically fused at the $\mathrm{N}$-terminal end.

\section{Computational analysis}

The nucleotide and corresponding amino acid sequences of the $X$. citri opp $A$ gene (GenBank accession number NC003919) were made available by the NCBI. Prediction of signal peptide and transmembrane sequences were determined with SignalP and DAS programs, respectively (http://www.cbs.dtu.dk/services/SignalP/ and http://www.sbc.su.se/ miklos/DAS/). Protein parameters of the $X$. citri OppA were calculated with the application of programs available at the Expasy Molecular Biology Server (http://www.au.expasy.org/).

\section{Protein expression}

Cultures of the recombinant E. coli BL21 (DE3) strain carrying pETOppA were grown aerobically in Erlenmeyer flasks containing LB with $50 \mu \mathrm{g} / \mathrm{mL}$ kanamycin until mid-log phase $\left(\mathrm{OD}_{600}=0.7-0.8\right)$ before addition of inducer $(0.2 \mathrm{mM}$ IPTG $)$. The cultures were induced aerobically $(200 \mathrm{rpm})$ either for 2 or $4 \mathrm{~h}$ or statically overnight at different temperatures $\left(23^{\circ}, 28^{\circ}\right.$ and $37^{\circ} \mathrm{C}$ ). Higher expression levels were achieved after evaluating different induction parameters including growth medium, aeration and incubation temperature during the induction period. Cells were collected by centrifugation and stored at $-20^{\circ} \mathrm{C}$ for approximately $16 \mathrm{~h}$ before preparation of the cell extracts. Cell pellets from 1-L cultures were suspended in $10 \mathrm{~mL} 10 \mathrm{mM}$ Tris-Cl, pH 8.0, $100 \mathrm{mM} \mathrm{NaCl}, 0.5 \mathrm{mM}$ PMSF, and $3 \mathrm{mM}$ imidazole, and incubated with lysozyme (final concentration of $100 \mu \mathrm{g} / \mathrm{mL}$ ) for $1 \mathrm{~h}$ in an ice bath. Cells were maintained in ice and sonically disrupted after 5 pulses of $15 \mathrm{~s}$ in a Branson Digital Sonifier (Model 450) followed by centrifugation at 18,000 rpm for 20 min to obtain the soluble and non-soluble proteins.

\section{Purification and refolding of $X$. citri OppA}

The recombinant OppA was purified from insoluble fractions after solubilization with buffer B (50 mM Tris-Cl, pH 8.0, $150 \mathrm{mM} \mathrm{NaCl}, 8 \mathrm{M}$ urea) and addition of nickel-charged Sepharose (ProBond, Invitrogen) slurry ( $1 \mathrm{~mL}$ resin per $15 \mathrm{mg}$ total protein), previously washed with 2 volumes of water and 1 volume of buffer $\mathrm{B}$, and incubated for $1 \mathrm{~h}$ under mild agitation. The charged resin was transferred to a plastic column and washed with 10 volumes of buffer $B$ with $10 \mathrm{mM}$ imi- 
dazole added, followed by washing with 3 volumes of buffer B plus $20 \mathrm{mM}$ imidazole. The bound OppA was serially eluted using buffers with increasing imidazole concentration. After purification, eluted samples were submitted to SDS-PAGE to confirm purity and protein concentration. Refolding of the denatured protein was attempted by both dialysis and dilution methods, but successful results were achieved only with the dilution method in which protein aliquots (approximately $2 \mathrm{mg}$ ) diluted with 100-fold volumes of refolding buffer (PBS, pH 7.4, $1 \mathrm{M}$ urea, 10\% glycerol, $0.005 \%$ Tween 20, $0.5 \mathrm{mM}$ PMSF and $5 \mathrm{mM}$ DTT) were maintained under vigorous agitation at $4^{\circ} \mathrm{C}$ for $8 \mathrm{~h}$. The total volume was concentrated on Amicon filters centrifuged at $18,000 \mathrm{rpm}$ at $4^{\circ} \mathrm{C}$ for 20 min, followed by dialysis with $10 \%$ glycerol and $0.5 \mathrm{mM}$ PMSF in PBS, $\mathrm{pH} 7.4$, followed by three dialysis steps with $20 \mathrm{mM}$ Tris- $\mathrm{Cl}, \mathrm{pH} 8.0$, and $50 \mathrm{mM} \mathrm{NaCl}$. After centrifugation, the soluble fractions were concentrated with Ultrafree MWCO 30,000 centrifugal filters (Amicon Millipore) and analyzed on $12 \%$ acrylamide gels stained with Coomassie blue. In all steps, the protein concentration was determined spectrophotometrically using the Edelhoch method (1967).

\section{Circular dichroism}

Circular dichroism (CD) measurements were carried out with a JASCO J-810 spectropolarimeter equipped with a Peltier-type temperature controller and a thermostated cell holder interfaced with a thermostatic bath. Spectra were recorded in $0.1-\mathrm{cm}$ path length quartz cells at a protein concentration of $5 \mu \mathrm{M}$ in $20 \mathrm{mM}$ Tris- $\mathrm{HCl}$ buffer, at $\mathrm{pH} 8.0$, and containing $50 \mathrm{mM} \mathrm{NaCl}$. Twenty consecutive scans were compiled and the average spectra stored. The data were corrected for the baseline contribution of the buffer and the observed ellipticities converted into the mean residue ellipticities $[\theta]$, based on a mean residue molecular mass of $219.2 \mathrm{kDa}$. The secondary structure was estimated from fitted far-UV CD spectra using the DICROPROT software package (Deléage and Geourjon, 1993).

\section{RESULTS}

\section{Expression and purification of the recombinant $X$. citri OppA}

X. citri OppA has 539 amino acid residues, including a putative signal peptide with 19 amino acid residues and a cleavage site located between Ala19 and Gly20. Specific primers were thus designed in order to amplify a $1.5-\mathrm{kbp}$ fragment containing the $X$. citri oppA sequence. The fragment was cloned in an intermediate vector (pGEMT) before subsequent forced cloning into the NdeI and HindIII restriction sites of pET28a, which resulted in the pETOppA expression vector. The recombinant OppA of $X$. citri was expressed and purified from E. coli BL21 (DE3) under the control of the $\mathrm{T} 7$ phage promoter as a cytosolic protein genetically fused to an $\mathrm{N}$-terminal $\mathrm{His}_{6}$-tag. Attempts to express the recombinant protein with its native signal peptide and a C-terminal $\mathrm{His}_{6}-$ tag showed that $E$. coli BL21 (DE3) was unable to secrete the heterologous OppA to the periplasm (data not shown). The maximal expression yields varied from 60 to $200 \mathrm{mg} / \mathrm{L}$, corresponding up to $30 \%$ of the total cell protein (Figure 1A). Different induction protocols based on variation of incubation temperature, aeration and induction time were tested in order to optimize the expression yields of the recombinant protein (Table 1). Under the tested conditions, maximal protein expression levels were achieved in cultures prepared in LB medium at $28^{\circ} \mathrm{C}$ with no aeration, which resulted in a final protein yield of $200 \mathrm{mg} / \mathrm{L}$ (Figure 1B, Table 1). Under all tested growth conditions, 
only a small amount of the expressed protein (less than $10 \%$ of the total purified protein) remained soluble but readily precipitated upon storage, precluding its use for further experiments (Table 1). Extended induction periods at lower temperatures and cultivation in M9 medium with no aeration did not improve the solubilization of the recombinant protein, which remained largely insoluble as inclusion bodies. Similarly, no further improvements were achieved with different $E$. coli host strains (data not shown). Therefore, purification of the recombinant protein required a denaturation step with $6 \mathrm{M}$ urea.

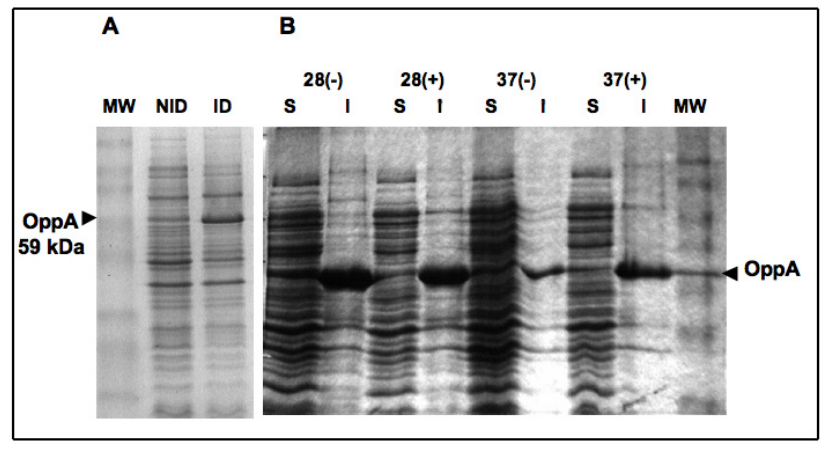

Figure 1. Expression of recombinant Xanthomonas citri OppA in Escherichia coli BL21 (DE3) cells transformed with the pETOppA vector. A. Whole-cell extracts of non-induced (NID) or IPTG-induced (ID) cultures were loaded on polyacrylamide gels after cultivation in $\mathrm{LB}$ medium at $37^{\circ} \mathrm{C}$. B. Production of the recombinant OppA under different growth conditions. Cultures were incubated with no agitation (-) or at $200 \mathrm{rpm}(+)$. Soluble (S) and insoluble fractions (I) of whole-cell lysates are indicated. MW: pre-stained molecular weight.

Table 1. Experimental conditions affecting the expression levels of soluble and insoluble recombinant Xanthomonas
citri OppA.
\begin{tabular}{lcccccc}
$\begin{array}{l}\text { Induction } \\
\text { temperature }{ }^{1} \\
\left({ }^{\circ} \mathrm{C}\right)\end{array}$ & Aeration $^{2}$ & $\begin{array}{c}\text { Culture } \\
\text { medium }^{3}\end{array}$ & $\begin{array}{c}\text { Induction }_{\text {period }^{4}} \\
(\mathrm{~h})\end{array}$ & $\begin{array}{c}\text { Total } \\
\text { protein }^{5} \\
(\mathrm{~g} / \mathrm{L})\end{array}$ & $\begin{array}{c}\text { Soluble } \\
\text { protein }^{6} \\
(\mathrm{~g} / \mathrm{L})\end{array}$ & $\begin{array}{c}\text { Insoluble } \\
\text { protein }^{7} \\
(\mathrm{~g} / \mathrm{L})\end{array}$ \\
\hline 37 & & LB & 2 & 0.120 & 0.020 & 0.100 \\
37 & + & LB & 4 & 0.060 & - & 0.060 \\
28 & - & LB & 2 & 0.200 & 0.010 & 0.190 \\
28 & + & LB & 4 & 0.200 & 0.020 & 0.180 \\
\hline
\end{tabular}

${ }^{1}$ Incubation temperature following addition of inducer to the bacterial culture, as described in the text; ${ }^{2}$ Cultures kept in flasks on an orbital shaker set at $200 \mathrm{rpm}(+)$ or kept static (-) during the induction period; ${ }^{3} \mathrm{LB}$ - Luria broth; ${ }^{4}$ Cultures were kept under inducing conditions for 2 or $4 \mathrm{~h} ;{ }^{5}$ Total protein yields as obtained with 1-L cultures kept in 3.6-L Fernbach flasks; ${ }^{6}$ Amount of soluble protein in the cell extracts; ${ }^{7}$ Amount of insoluble protein obtained as inclusion bodies.

Once bound to the nickelated resin, the recombinant protein was recovered after elution with imidazole-containing buffer at concentrations ranging from 200 to $300 \mathrm{mM}$ (Figure 2A, lanes 4-7). A large amount of OppA was lost during washing steps required to remove contaminant endogenous proteins. The best recovery yields were achieved after extensive washing (5- to 20-fold bed column volume) at an imidazole concentration of $20 \mathrm{mM}$. Based on this protocol, approximately $70 \%$ of the total recombinant protein was recovered with a final protein yield of $120 \mathrm{mg} / \mathrm{L}$. 


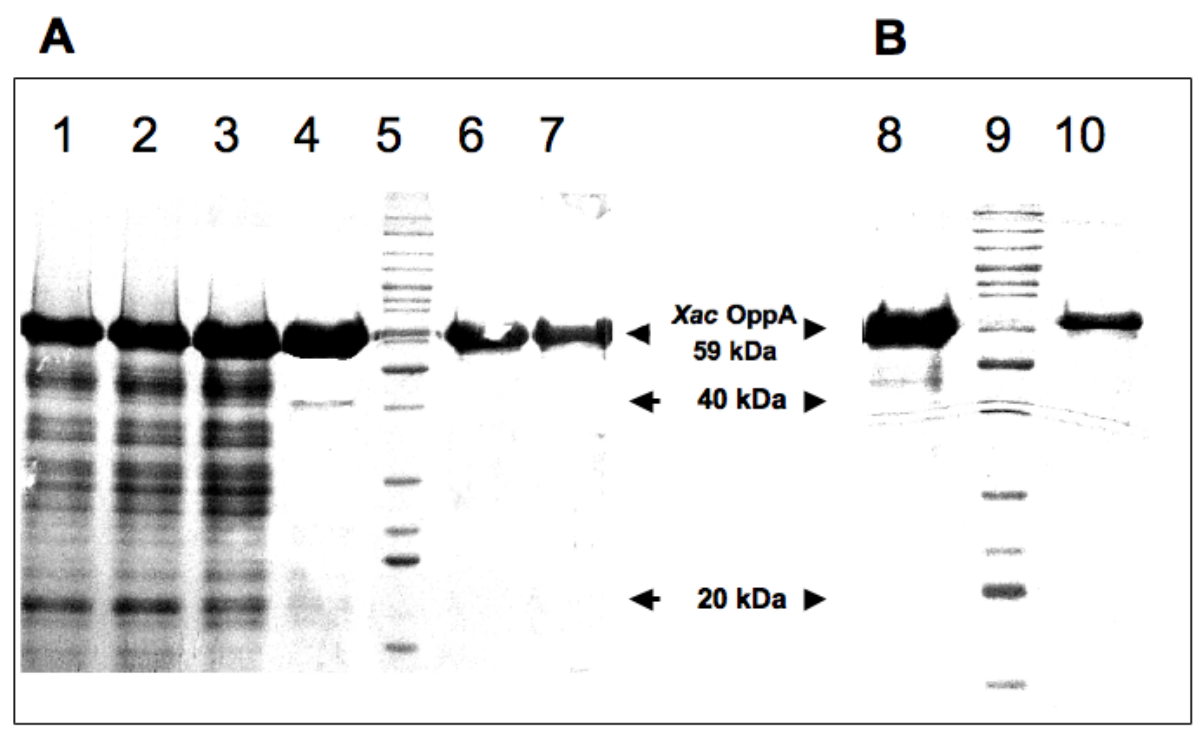

Figure 2. Purification of the recombinant Xanthomonas citri (Xac) OppA by immobilized metal affinity chromatography (A) and subsequent refolding of the denatured protein (B). Lane 1, flow through; lanes 2 and 3, fraction recovered following washing with imidazole at concentrations of 20 and $50 \mathrm{mM}$, respectively; lanes 4, 6 and 7, fractions eluted with buffers containing 100, 200 and $300 \mathrm{mM}$ imidazole, respectively; lanes 5 and 9 , pre-stained molecular weight markers (Invitrogen); lanes 8 and 10, purified OppA samples before and after the refolding procedure, respectively.

\section{X. citri OppA refolding and circular dichroism analysis}

The amino acid sequence analysis using bioinformatics methods revealed a protein consisting of $51.2 \%$ nonpolar, $27.3 \%$ uncharged polar, $10 \%$ acidic and $9.3 \%$ basic residues and a predicted $\mathrm{pI}$ of 6.5 . Comparison of the primary sequence of X. citri, S. typhimurium and $B$. subtilis OppA orthologs indicated that the $X$. citri ortholog has a higher nonpolar residue content and, therefore, classified as an unstable protein (instability index of 42.33), in comparison with the orthologs expressed by B. subtilis and S. typhimurium (instability index of 23.06 and 33.14, respectively). Corroborating the unstable nature of the recombinant protein, refolding of the denatured protein using conventional dialysis method resulted in protein precipitation (data not shown). Better results were obtained after refolding of the denatured protein using a dilution method followed by dialysis steps. Based on such procedure, $20 \%$ of the total purified protein was recovered in a soluble state (Figure 2B). The purified refolded protein remained soluble $(1-3 \mathrm{mg} / \mathrm{mL})$ even when stored at $4^{\circ}$ or $-20^{\circ} \mathrm{C}$.

The CD spectrum of the soluble refolded recombinant $X$. citri OppA was characterized by a relative maximum at $195 \mathrm{~nm}$ and two relative minima at 208 and $222 \mathrm{~nm}$, suggesting that the protein preserved its native structure (Figure 3). The correct refolding of $X$. citri OppA was confirmed by comparison with the CD spectra of the E. coli OppA ortholog (very high sequence identity with $S$. typhimurium protein). 


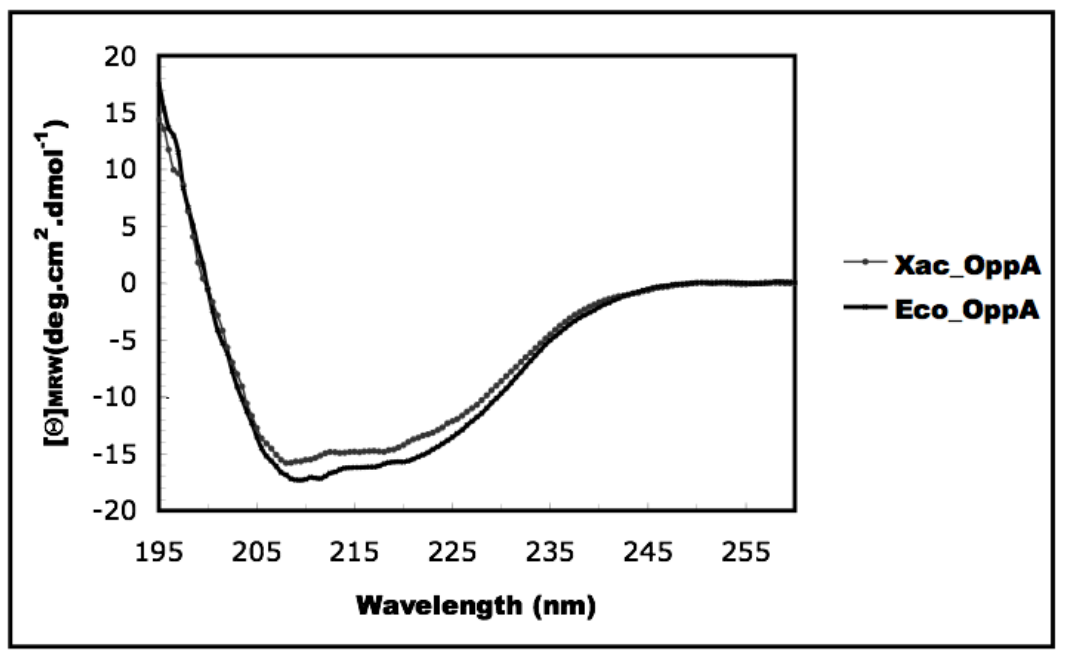

Figure 3. Circular dichroism spectra of the recombinant Xanthomonas citri (Xac) OppA protein expressed by Escherichia coli cells and the E. coli (Eco) OppA purified from periplasmic fractions (Nakamatsu et al., 2007). Purified protein samples were prepared to a final concentration of $10 \mu \mathrm{M}$ in $20 \mathrm{mM}$ Tris-Cl, $\mathrm{pH} 8.0$, and $50 \mathrm{mM}$ $\mathrm{NaCl}$. Circular dichroism spectrum of the recombinant OppA is characteristic of an $\alpha / \beta$ protein. $\mathrm{MRW}=$ mean residue molecular mass.

The predicted secondary structure of the recombinant protein, carried out with the DICROPROT program, indicated that the overall OppA structure encompassed $35 \%$ $\alpha$-helices and $22 \% \beta$-strands while turns and random coils represented $43 \%$ of the predicted protein secondary structure. Similar secondary structures were reported for the $S$. typhimurium and B. subtilis orthologs with solved three-dimensional structures (Tame et al., 1996; Levdikov et al., 2005), as indicated in Table 2.

\begin{tabular}{|c|c|c|c|c|c|c|c|}
\hline \multirow[t]{2}{*}{ Bacterium } & \multirow{2}{*}{$\begin{array}{c}\text { Total } \\
\text { number }^{3}\end{array}$} & \multicolumn{3}{|c|}{ OppA amino acid composition ${ }^{1}$} & \multirow[t]{2}{*}{ Isoleucine/Proline ${ }^{4}$} & \multicolumn{2}{|c|}{ Conformation $^{2}$} \\
\hline & & $\begin{array}{l}\text { Charged } \\
\text { amino acid }\end{array}$ & $\begin{array}{c}\text { Polar } \\
\text { amino acid }\end{array}$ & $\begin{array}{l}\text { Nonpolar } \\
\text { amino acid }\end{array}$ & & $\begin{array}{c}\alpha- \\
\text { helix }\end{array}$ & $\begin{array}{c}\beta- \\
\text { sheet }\end{array}$ \\
\hline Xac & 519 & 19.3 & 26.7 & 45.3 & $2.6 / 5.9$ & 35 & 22 \\
\hline Sty & 518 & 24.7 & 29.2 & 35.6 & $4.4 / 6.0$ & 36 & 18 \\
\hline Bsu & 520 & 29.0 & 27.7 & 34.0 & $5.2 / 4.0$ & 37 & 26 \\
\hline
\end{tabular}

${ }^{1}$ Relative composition of charged, polar and nonpolar residues expressed as percentages of total residues of the respective mature proteins expressed by X. citri, S. typhimurium and B. subtilis; ${ }^{2}$ Major secondary structures as determined from sequence details of the PDB pages of $B$. subtilis (PDB entry 1XOC) and $S$. typhimurium OppA (PDB entry 1OLA) orthologs. ${ }^{3}$ Total number of amino acid residues of each protein; ${ }^{4}$ Proline and isoleucine content of the OppA proteins expressed as percentages of the total amino acid residues of the mature protein. 


\section{DISCUSSION}

The ATP-binding cassette $(\mathrm{ABC})$ transporters comprise one of the largest paralogous protein families comprising as much as $5 \%$ of bacterial genomes and controlling the traffic of essential nutrients (Higgins, 2001). The oligopeptide (Opp) permeases, one of the most comprehensively studied ABC transporter systems, encompass a set of membrane-associated proteins responsible for the binding and translocation of peptides ranging from 3 to at least 18 amino acid residues. Moreover, besides its primary role in peptide uptake, the Opp system, and particularly OppA orthologs, has been implicated in various physiological processes required for survival in different environmental conditions including recycling of cell wall peptides, inter-cellular communication, sporulation, binding to host tissues and proteins as well as survival at low temperatures or in intracellular environments (Perego et al., 1991; Cundell et al., 1995; Claverys et al., 2000; Borezee et al., 2000; Monnet, 2003). However, little is known about the role of the Opp system in plant bacterial pathogens, particularly those belonging to the Xanthomonas genus, which includes several species affecting economically important cultivars. In the present report, we described for the first time the expression and purification of a soluble OppA encoded by $X$. citri, the etiological agent of citrus canker, one of the most relevant diseases affecting the orange juice industry and citrus farmers.

The oppA-encoding gene has been amplified from the genomic DNA of the $X$. citri 306 strain, which has been shown to carry a single copy of the opp operon (Da Silva et al., 2002). Genes encoding the Opp system have been found in many but not all bacterial species. The discovery that two closely related Xanthomonas species, X. citri and X. campestris, differ in the presence of the opp genes suggests that the uptake of peptides plays distinct physiological roles in these species. For example, X. campestris has been shown to carry a set of genes involved in the reduction of nitrate and nitrite to ammonium. Such genes, not found in the $X$. citri genome, would allow the bacteria to grow in nutrient-poor environments such as the xylem of host plants where nitrate would represent the most readily available nitrogen source. On the other hand, $X$. citri has been shown to encode several specific proteases, which generate peptides to be used as the main nitrogen source, thus allowing bacterial cells to thrive in necrotic lesions generated during infection (Da Silva et al., 2002).

Previous attempts to express $X$. citri proteins carrying the native signal sequences did not result in accumulation of the encoded peptides in the periplasm of recombinant $E$. coli strains, suggesting that differences in signal sequence length and charged residue composition negatively affect recognition of the nascent peptide by the membrane-associated protein secretion apparatus (Balan et al., 2005). Removal of the signal peptide and fusion of the $\mathrm{His}_{6}-$ tag to the N-terminal region has been the best experimental approach to express and purify $X$. citri nutrient-binding proteins, resulting in soluble proteins at nearly homogeneous and stable states (Evdokimov et al., 2001; Balan et al., 2005, 2006). Expression of the recombinant OppA in E. coli strains systematically resulted in the accumulation of an insoluble protein, and only a small fraction of the encoded peptide remained soluble, which readily precipitated. The higher nonpolar amino acid residue content of the X. citri OppA mature protein (45\%), with regard to the orthologs expressed by E. coli and S. typhimurium (approximately 35\%), has probably contributed to the observed behavior of the recombinant protein expressed in E. coli strains. The reduced isoleucine content of the $X$. citri OppA, with regard to the orthologs from $E$. coli and $B$. subtilis, may also contribute to the comparatively lower solubility of the recombinant 
protein (Table 2). Indeed, as demonstrated by Evdokimov et al. (2001), the proline and isoleucine contents, as well as their presence at specific positions, confer a remarkable stability to a recombinant Pyrococcus furiosus maltose-binding protein.

Attempts to employ different $E$. coli host strains, cultivated under various growth conditions and using diverse gene expression inducing protocols did not enhance the solubility of the recombinant protein. Since one of our interests was the generation of soluble protein adequate for conformational and structural studies, an alternative purification procedure involving denaturation and refolding of the recombinant protein was established. Although, different methods of refolding are described in the literature (Tsumoto et al., 2003; Bondos and Bicknell, 2003), the recombinant $X$. citri OppA was successfully refolded only after dilution of the protein at low concentrations in the presence of glycerol that facilitated the proper folding and stability of the protein. Curiously, the protein refolding using the same buffer but on dialysis resulted in protein precipitation. The success of the high dilution refolding protocol may be ascribed to the vigorous stirring of the sample during the whole process. Indeed the same refolding procedure has been successfully used in other $X$. citri nutrient-binding proteins (Balan A and Perez-Santacruz C, unpublished observations).

The availability of purified OppA protein represents an important step toward the definition of functional and structural features of the X. citri Opp system. Although the native protein proved to be particularly difficult to obtain in a soluble state, the dilution method established in this study is more convenient in terms of handling, time and cost than the dialysis method and will be useful for large-scale production of the protein for crystallization trials and structural studies.

\section{ACKNOWLEDGMENTS}

Research supported by a FAPESP grant to the Structural and Molecular Biology Net Program (SMolBNet). We thankfully acknowledge the helpful technical assistance of C.C. Perez.

\section{REFERENCES}

Balan A, de Souza CS, Moutran A, Ferreira RC, et al. (2005). Purification and in vitro characterization of the maltosebinding protein of the plant pathogen Xanthomonas citri. Protein Expr. Purif. 43: 103-110.

Balan A, Santacruz CP, Moutran A, Ferreira RC, et al. (2006). The molybdate-binding protein (ModA) of the plant pathogen Xanthomonas axonopodis pv. citri. Protein Expr. Purif. 50: 215-222.

Bondos SE and Bicknell A (2003). Detection and prevention of protein aggregation before, during, and after purification. Anal. Biochem. 316: 223-231.

Borezee E, Pellegrini E and Berche P (2000). OppA of Listeria monocytogenes, an oligopeptide-binding protein required for bacterial growth at low temperature and involved in intracellular survival. Infect. Immun. 68: 7069-7077.

Brunings AM and Gabriel DW (2003). Xanthomonas citri: breaking the surface. Mol. Plant Pathol. 4: 157.

Claverys JP, Grossiord B and Alloing G (2000). Is the Ami-AliA/B oligopeptide permease of Streptococcus pneumoniae involved in sensing environmental conditions? Res. Microbiol. 151: 457-463.

Cundell DR, Pearce BJ, Sandros J, Naughton AM, et al. (1995). Peptide permeases from Streptococcus pneumoniae affect adherence to eucaryotic cells. Infect. Immun. 63: 2493-2498.

Da Silva AC, Ferro JA, Reinach FC, Farah CS, et al. (2002). Comparison of the genomes of two Xanthomonas pathogens with differing host specificities. Nature 417: 459-463.

Deléage G and Geourjon C (1993). An interactive graphic program for calculating the secondary structure content of proteins from circular dichroism spectrum. Comput. Appl. Biosci. 9: 197-199.

Edelhoch H (1967). Spectroscopic determination of tryptophan and tyrosine in proteins. Biochemistry 6: 1948-1954.

Genetics and Molecular Research 7 (1): 117-126 (2008)

CFUNPEC-RP www.funpecrp.com.br 
Evdokimov AG, Anderson DE, Routzahn KM and Waugh DS (2001). Structural basis for oligosaccharide recognition by Pyrococcus furiosus maltodextrin-binding protein. J. Mol. Biol. 305: 891-904.

Gominet M, Slamti L, Gilois N, Rose M, et al. (2001). Oligopeptide permease is required for expression of the Bacillus thuringiensis plcR regulon and for virulence. Mol. Microbiol. 40: 963-975.

Goodell EW and Higgins CF (1987). Uptake of cell wall peptides by Salmonella typhimurium and Escherichia coli. J. Bacteriol. 169: 3861-3865.

Higgins CF (2001). ABC transporters: physiology, structure and mechanism - an overview. Res. Microbiol. 152: 205210.

Lazazzera BA, Solomon JM and Grossman AD (1997). An exported peptide functions intracellularly to contribute to cell density signaling in Bacillus subtilis. Cell 89: 917-925.

Lee HM, Chen JR, Lee HL, Leu WM, et al. (2004). Functional dissection of the XpsN (GspC) protein of the Xanthomonas campestris pv. campestris type II secretion machinery. J. Bacteriol. 186: 2946-2955.

Levdikov VM, Blagova EV, Brannigan JA, Wright L, et al. (2005). The structure of the oligopeptide-binding protein, AppA, from Bacillus subtilis in complex with a nonapeptide. J. Mol. Biol. 345: 879-892.

Monnet V (2003). Bacterial oligopeptide-binding proteins. Cell Mol. Life Sci. 60: 2100-2114.

Moutran A, Quaggio RB, Balan A, Ferreira LC, et al. (2004). The oligopeptide permease (Opp) of the plant pathogen Xanthomonas axonopodis pv. citri. Curr. Microbiol. 48: 354-359.

Nakamatsu EH, Fujihira E, Ferreira RC, Balan A, et al. (2007). Oligopeptide uptake and aminoglycoside resistance in Escherichia coli K12. FEMS Microbiol. Lett. 269: 229-233.

Perego M (1997). A peptide export-import control circuit modulating bacterial development regulates protein phosphatases of the phosphorelay. Proc. Natl. Acad. Sci. U. S. A. 94: 8612-8617.

Perego M, Higgins CF, Pearce SR, Gallagher MP, et al. (1991). The oligopeptide transport system of Bacillus subtilis plays a role in the initiation of sporulation. Mol. Microbiol. 5: 173-185.

Rudner DZ, LeDeaux JR, Ireton K and Grossman AD (1991). The spo0K locus of Bacillus subtilis is homologous to the oligopeptide permease locus and is required for sporulation and competence. J. Bacteriol. 173: 1388-1398.

Tame JR, Sleigh SH, Wilkinson AJ and Ladbury JE (1996). The role of water in sequence-independent ligand binding by an oligopeptide transporter protein. Nat. Struct. Mol. Biol. 3: 998-1001.

Tsumoto K, Ejima D, Kumagai I and Arakawa T (2003). Practical considerations in refolding proteins from inclusion bodies. Protein Expr. Purif. 28: 1-8. 